\title{
The French Revolution and the Craft of the Liminal Void: From the Sanctity of Power to the Political Power of the Limitless Sacred
}

\author{
CAMIL FRANCISC ROMAN*
}

Francouzská revoluce a tvorba liminální prázdnoty: Od svátosti moci k politické síle bezmezného posvátna

\begin{abstract}
This paper argues for a political anthropological approach to the study of the French revolution. Looking at the revolution as a moment of liminality, it substantiates two interconnected points. The first is that a proper understanding of the revolutionary dynamic and its lasting effects have to engage closely with the transformation of the sacred and its relation to the existential void. Situated in post-Durkheimian sociology and post-Kantian philosophy, this argument advocates the methodological normalization of metaphysics, drawing attention to the fact that faith belongs to the symbolic, existential and representational realities of any political order, and hence also of its underlying knowledge systems. The second point argues that through the sacrifice of Louis XVI, the French revolution consecrated the ritual and existential sacrifice of the Christian Father. This historical experience is conceptualized as the people's third body, and the new configuration of the sacred to which it gives birth is interpreted in terms of the liminal void. In this way, the French revolution is shown to constitute the transition from a political order of embodiment - participation in the divine, symbolized by the sacred royal body to a political order of bodies; participation in the liminal void, symbolized by the sacred empty place of the power of the modern democratic imagination.
\end{abstract}

Keywords: French revolution; liminality; genealogy; sacred; post-Kantianism; modern democracy; the third body of the people; secularization

DOI: $10.14712 / 23363525.2018 .39$

\section{Introduction: From Political Embodiment to Political Bodies}

In this paper, I draw a large bow around the methodological assumptions underlying by far the largest part of the scholarly work on the French revolution. Inasmuch as the revolution was about the social overcoming of the sacred monarchy and of a political power that explicitly assumed Christian metaphysical participation in reality, the analysis and interpretation of this event must bring clarity into the problematic of the sacred and its relation to power and political order. Even more, it has to be able to deal with the concrete person of Louis XVI as the embodiment of the royal sacred and as a Christian prince trying to make sense of the world around him and acting (and non-acting) accordingly. Yet, puzzling as it is, this is exactly not what the enormous literature on the French revolution achieves. Instead, the interpretation and analysis of the revolution focuses almost exclusively on the implicit or explicit secular narrative of progressive versus non-progressive

\footnotetext{
Dr. Camil Roman, Lecturer in Political Science at John Cabot University, LUMSA University and Roma Tre University. E-mail: croman@johncabot.edu.
} 
forces, the yardstick for understanding the revolutionary change and modern democratic power being given by the dynamic between the three programmatic values of the revolution: freedom, equality, and brotherhood. The result is a dominant discourse that overstates the case of various social, economic, and political forms of rationalism. On the rare and cursory occasions when the sacred is addressed, it is reduced in Durkheimian fashion to a mere social construct of varying importance and the previous (Christian) "religious" relegated to a regressive logic of history or an epistemological "misrecognition."

Rather than taking this status quo for granted, this must be problematized and hence understanding the methodological underpinnings of the modernist literature becomes necessary. As I will show in this paper, at stake is nothing less but that which constitutes human experience itself. In order to grasp the experiential level of the revolutionary dynamic, I take a political anthropological approach to the subject matter. Political anthropology refers not simply to the concern with political power, but also with overcoming the methodological opposition between the individual and the state, and the social and the political. It is aiming at retrieving the link between political order and constitutive historical experience, connecting them to the existential elements of personhood [Szakolczai 2008; Lefort 1988; Wydra 2012]. This existential dimension underscores processes of meaning formation, and the way symbols allow members of society to represent themselves and experience society as of their human essence. Accordingly, every political order in history reflects exactly the type of men of which it is composed [Voegelin 1987: 27-106]. The consequence of such a perspective is that the sacred has to be brought back into the analysis, not along the lines of a Durkheimian reductionism [Durkheim 1967; AlexanderGiesen - Mast 2006] but in the full recognition that there is an ontological-metaphysical dimension to reality - we are not simply bodies, but also embodiments - that cannot be controlled or purified by the modern scientific method and philosophy (moderno-centrism). In the present context, this means that the paper departs from both (Neo-)Kantian/ liberal theorizing and (Neo-)Marxist/socialist diagnosticating, both of them being in fact closely intertwined via "critique."

The way I propose to overcome moderno-centrism at the conceptual level is by using the approach of liminality and looking at the revolution essentially as a ritual event gone "mad." With this move, I am able to substantiate two points. The first is that a key part of the revolutionary dynamic and the transformation of the sacred therein was the presence of the liminal or existential void. "Eventifying" history on a methodological level [Nietzsche 1967; Weber 2016; Foucault 1979; Foucault 1984; Sewell 2005] involves not only breaking down any "mechanism" into a process of social change, but also recognizing the underlying emotional charges with the void on a substantive/ontological level, providing the link between two distinct forms. The second point is that the historical mediation for the transformation of the sacred is what I call the "people's third body," or in other words, the symbolic and existential sacrifice of the Christian Father through the ritual sacrifice of Louis XVI. This new sacred form ordering the world-view and sociological reality of the people became symbolized by the empty democratic place of power and is interpreted here in terms of the liminal void. In this way, the French revolution is shown to mark the threshold of the movement from a political order of embodiment - which provides for a participatory ontology within a Christian metaphysical world-view, and which is symbolized by the sacred royal body - to a political order of bodies providing for a participatory 
ontology in the liminal void, and which is symbolized by the sacred empty place of power. With this transition, political power lost its former characteristic of sanctity, becoming attached to a type of the sacred that in its concrete manifestation can encompass - because of itself essentially formless - any immanent category of human existence. Contrary to common presumptions, this makes the sacred not a thing of the past, but rather shows its potentially limitless nature in secularized modernity. This claim cannot be pursued here any further but has to be already stated as such and also connected as a conjecture with the modern tendency to limitless conflict and perpetual crisis.

\section{Outline of the Argument}

In the following I start by introducing the concept of liminality, explaining how to understand its methodological application to the French revolution. Next, I trace the experiential source of moderno-centrist interpretations of the revolution to the liminal void - the point of existential suspension - that, if taken as an all-encircling reality, leads to a kind of metaphysics and scientific discourse that annihilates the truth and actuality of any concrete mode of experience in history. I identify the source of this kind of reasoning in Kant's natural and critical philosophy, Kant being also the exact contemporary of the French revolution. In a subsequent step, I link Kantianism as a symbol of knowledge standing for modernist philosophy more generally, to the historical literature of the French revolution, highlighting its shortcomings. After this and given the constraints of a paper, rather than going into the details of the events of the French revolution and tracking down the symbolic and existential disincorporation of the royal sacred, ${ }^{1} \mathrm{I}$ follow here a different route and discuss the revolution by taking to aid Harald Wydra's work on the liminal origins of democracy and Claude Lefort's idea of the "empty place of power." This allows me to show how to understand the transformation of the sacred in terms of the liminal void that - via the "people's third body" - became a constitutive part of modern democratic power and imagination. Finally, I conclude by bringing together the potential methodological and substantive contributions of my paper to the field of the French revolution, historical sociology, and the human sciences more generally.

\section{Thinking the French Revolution with Liminality}

Liminality was first used in order to grasp the threshold situation in which communities found themselves while going through a rite of passage [Gennep 1960 (1909)]. After a rather long dry spell in which the concept was marginalized, ${ }^{2}$ Victor Turner's anthropology of experience [1969, 1985] picked up the hints provided by Gennep and suggested the use of the concept for the study of large-scale societies. From that moment scholars across disciplines used its theoretical and methodological propositions to study transformative

\footnotetext{
For a comprehensive political anthropological analysis and interpretation of the French revolution, see my doctoral thesis [Roman 2017], currently in preparation as a research monograph for Routledge.

2 For a highly insightful and comprehensive conceptual history of liminality, outlining in the same time the concept's analytic purchase and boundaries, see Thomassen [2014: 1-110].
} 
periods involving modern societies and whole epochs [Eisenstadt 1995; Szakolczai 2000, 2015; Horvath - Thomassen - Wydra 2015; Roman 2018]. ${ }^{3}$

Yet what is at stake in liminality? The frequent failure to address such crisis moments like revolutions and wars is closely linked to the difficulty of grasping the unsystematizable, unquantifiable and irrational of historical experience itself. In this context, liminality is well placed to provide not simply a valuable key, but maybe the key to the problem. This is so because liminality is not yet another un-reflexive theory invented by the transcendental mind, but potentially the closest the social sciences have ever come to a universal "living fact." 4 This is the discovery that moments of personal and collective transition are organized and controlled socially through a ritual passage that can be divided into three parts: rites of separation, rites of transition and rites of incorporation [Gennep 1960]. Making the junction between Gennep's work and Dilthey's philosophy of life, between liminality and experience, Turner and Szakolczai recognized that the tripartite ritual process of the rites of passage describes nothing less than the structure of lived experience [Thomassen 2014: 88]. ${ }^{5}$ In other words, liminality refers to an event in which we go through something; it is the process of a concrete spatial and emotional crossing of boundaries. As such, it brings into focus how people behave in relation to any in-between situation or object, any in-between place or moment [Thomassen 2014: 1-7].

From this follows four interconnected and highly significant points. The first is the recognition that liminality allows us to approach revolutions, and indeed any moment of radical uncertainty, not from a cause-outcome perspective but by emphasizing the transformative power of the situations which are lived through in such events [Wydra 2007: 32]. This can be done not simply by relegating the analysis to a discursivity of cultural change as established expost facto, overloading the newly created reality with justifying rationality, but by actually highlighting what is hidden or implied behind such discursivity. In this sense, liminality provides the conceptual tools for nothing short of a methodology of social change. It links up with genealogy and with approaches that eventify history, but also goes beyond them, grounding them methodologically.

The second point is that revolutions have to be analyzed as ritual events [Thomassen 2012]. Revolutions as events resemble rituals precisely because the ritual process provides the structure of human experience. Therefore, liminality suggests that the analysis concerning political power and the specific outlook of a political order has to be brought in connection with the way the ritual process is imagined, enacted, represented or broken. By the same token, the dissolution of political order during a revolution is primarily a breakdown of the social boundaries established by the ritual process underlying the manifestation of power. Seen from such an angle, the "discovery" of liminality necessitates nothing less than "re-writing" the very foundations of political anthropology. ${ }^{6}$

The third point is that liminality offers one possible way of overcoming moderno-centrist perspectives that are rather too closely entangled with the conditions that they are supposed to explain. The reason behind this is that liminality refers to ritual passages, or in

\footnotetext{
This list of works only provides a guide to the ways in which liminality is deployed here.

The expression belongs to van Gennep.

For experience as a formative event, or a transformation in the mode of being, see also the works of Eric Voegelin and Michel Foucault.

6 Indeed, such an attempt is currently under way [Wydra - Thomassen, forthcoming].
} 
other words, to "experience" as the crossing of existential boundaries, itself an inescapable given across cultures and times. In addition, the anthropologists developing the concept of liminality were working in non-modern contexts and responding precisely to the conceptual deficiencies that they noticed in their (moderno-centric) formation when dealing with their "material" on the ground.

Finally, liminality draws attention to the point of existential suspension marked by radical confusion and contingency, emptying reality of existential content while also giving it a new form. It is the emotional charges with the void characteristic of crises situations that remain entirely un-noticed and un-theorized in moderno-centric approaches to the French revolution. As I will show below, this is the case precisely because the liminal void has become the experiential source of modern political order and of its associated and supportive knowledge systems. It is within the context of the liminal void that the metaphysical, faith-based dimension of human life is purified out of reality. As a consequence, the sacred as the concern with the divine is entirely neglected in the interpretation of the revolution, and the transformation of the sacred achieved by the revolution is reduced to a mere social construct without any broader epistemological meaning.

\section{Moving Beyond Methodological Moderno-Centrism}

In his first 1983 lecture at the Collège de France, an inspired Foucault brought together two key texts by Kant, Was ist Aufklärung? [1784] - the famous essay taking up the question of what is the Enlightenment, and Der Streit der Fakultäten [1798] - a text that deals in addition to other things, also with the question of what is the Revolution. Among the many interesting points made by Foucault, two are of particular importance, both pertaining to Kant's effort of understanding his age. The first is that for Kant the "Revolution is actually the completion and continuation of the very process of Aufklärung" [Foucault 2010: 18], the reason for this being very simple: as Kant aims to demonstrate in his second text, the Revolution is a sign and proof of the continuous progress of humanity. The second significant observation regards the common underlying thread of the two texts: the "public" is singled out as the key marker enabling us to recognize the reality of Enlightenment and of progress [Foucault 2010: 7-21]. The basis for this theory is Kant's demonstration that, in order to understand the revolution's meaning as an event in history, its content is entirely irrelevant: what counts as the sign and proof of progress is "the sympathy of aspiration which borders on enthusiasm" of the spectators of the revolution, i.e. of those not directly involved in it as actors. From such premises, Kant constructs a "secular" progressive philosophy of history, modeling the entire existence of humans as a Theatrum Mundi, as a world reduced to an arena shared by actors and spectators, with the critics in the position of gods [Szakolczai 2012].

There are two reasons why this is important for my paper. For once, the argument that what happens inside the revolution is of no significance for understanding its meaning is as much a peculiar as it as a sociologically and historically absurd claim. Therefore, by following the spirit of genealogy [Nietzsche 1967; Weber 2016; Foucault 1979; Foucault 1984], this paper makes the reverse methodological argument: in order to grasp the meaning/ transformation of the revolution and its lasting effects (including in the field of knowledge forms), its events are exactly what we have to look at. Now, while this should seem like a 
normal, even trivial statement, it is not quite so as things get more complicated. The historical consequences of Kant taking his stance in the way he did have left deep marks on our methodological treatment of the revolution. With this, I am coming to my second point.

Between 1784 and 1798, the fourteen years time span lying between the two texts, Kant had the most productive years of his life, also providing for the philosophical and epistemological justification of his positions on the French revolution. In this way, he was at the "origin" of some of the most important subsequent philosophical developments: modern critical philosophy as a preoccupation with truth claims to ensue ultimately into modern scientific discourse in the human sciences, and the specifically modern answer regarding the direction of history, making the secular progressive philosophy of history something like a dogma. As I will show below, on an experiential basis, both of these are achieved by Kant by essentially purifying historical events of their intrinsic meaning and reality, or in other words, by looking at life through the lenses of the liminal void. With this new field of experience emerging and claiming a central place in reality, the thought of politics and its praxeology became the management and organization of bodies, or chaos theory. Putting it differently, modernist philosophy and politics became the concern with the aporia-ridden organization of symmetric relations between bodies along the axis of "liberté, égalité, fraternité," making the often forgotten second part of that motto - "ou la mort" - the (hidden) constitutive element of a sacrificial logic of the future.

\section{Kant and the Craft of the Liminal Void}

Right at the outset of the revolution, Immanuel Kant published his Critique of Practical Reason (1788) with a paragraph containing one of the most famous sentences of his entire career: "Two things fill the mind with ever new and increasing admiration and awe, the more often and steadily we reflect upon them: the starry heavens above me and the moral law within me." This pronouncement, however, is not just famous but can stay in place as motto for Kant's virtually entire philosophical work [Guyer - Wood 1998: 1-2] and in my view, it constitutes the key for grasping the way in which modern interpretations of the revolution overlook the presence of the existential void in the transformation of revolutionary power and are also unable to deal analytically with the sacred.

Since times immemorial up until the dawn of modernity, the vision of the sky has produced feelings evoking majestic beauty and an awe-inspiring connection to the eternal. Unsurprisingly, the sense of rapture produced by the vision of the sky was one of the most fundamental possibilities of discovering the divine element in the human soul and experiencing a life with meaning [O'Connor 2014]. In this regard, Kant did what human beings have always done: he connected the vision of the sky (the starry heavens) with meaning (the moral law). Yet despite apparent similarities, Kant's sky was exactly not the place of the encounter with the divine. With the advent of the scientific revolution in the 17 th century, a new image of the skies emerged, one dominated by modern astronomy and science, of which Kant was one of the most prolific actors [Schönfeld 2014].

In this new cosmological vision, Newtonian physics are credited with the most decisive modern introduction of the void as an empty space filled with bodies and forces. Not the forms and their inherent powers, but the void is now the founding principle and substance of the world, at once putting everything in motion and also nullifying each body and its 
identity through infinite decomposition and transmutability [Horvath 2013: 87-107]. Yet, while Newton never reached the vision of a purely mechanical cosmos deprived of the divine [Rynasiewicz 2014; Sallis 2012: 259-263], in Kant's natural philosophy the self-sufficient mechanics of colliding (creative) forces and bodies takes over, human beings and intelligent life, in general, becoming henceforth problems of understanding "matter density" [Schönfeld 2014]. As such, the "starry heavens" of Kant was not the place of divine order and harmony to participate in through the experience of serene beauty and almightiness. Rather, Kant was looking at the skies as a spectator in awe before the infinite and irrational play of forces of attraction and repulsion creating the cosmological chaos. In the face of such a cosmos, human life is literally nullified, becoming meaningless, even pointless. In this sense, the modern cosmological vision makes possible the experience of the ultimate liminal void, an encounter with the plainly "irrational" as the lack of measure, proportion, balance or harmony. ${ }^{7}$ Kant's natural philosophy has internalized and "rationalized" this irrational cosmos at a heavy price: now human experience itself is fragile and meaningless, in great need of a new anchor.

It is here that the critical project comes into play. Suggestively, Kant's intellectual effort is captured by Andrew Fiala in his introduction to Kant's Critique of Pure Reason in the following terms: "Kant's life is best described as heroic struggle to discover order within chaos or, better, an effort to fix human thought and behaviour within its proper limits" [2004: $v i i]$. This striking sentence illustrates the fundamental continuity of spirit between Kant's pre-critical period, concerned as it was with the effort of bringing "rational" order into the cosmological chaos, and his critical period in which he attempted to ground the problem of human life and experience within "new" limits. While recent philosophical literature has come to recognize a greater level of continuity in Kant's entire work (pre-critical, critical, and post-critical) than assumed previously [Edwards 2000], my point regards not the question of establishing connections between different substantive arguments based on their internal analytics, but continuity between two very different types of works (pre-critical and critical) based on a common experiential source [Voegelin 1974, 1987, 1990]. And here the crown jewel of his critical period - the method of the transcendental argument - is also the one to link Kant's experience of the liminal void present in his natural philosophy, to what has come to be known as his critical philosophical and political work.

This connection is realized in two steps. First, by enquiring into the a priori conditions for the possibility of human experience, Kant's transcendental philosophy deals with people as "bodies," standardizing them along with the ontology of the other bodies of the universe. ${ }^{8}$ Second and following from the first, once the epistemologically policed human subjects have been established as bodies, the transcendental argument is followed and expanded in a series of writings to engulf all human affairs, from politics to morality, religion, history, and law [Kant 1987, 1991, 2001, 2002]. By this, I mean that Kant constructs a discourse of knowledge that claims to be ontologically valid/true only in so far as it is independent of any substantive references to historically and/or empirically grounded

This use of the term "irrational" is deduced from the Latin etymology of ratio. Ratio refers to something that has the right proportions, is harmonic and in balance.

8 "I call all cognition transcendental that is occupied not so much with objects but rather with our a priori concepts of objects in general. A system of such concepts would be called transcendental philosophy" [Kant 1998, B 25 - A 12; 133]. 
experience. In this way, it is clear that Kant looks at human life from a point in cosmos the place of the ultimate void where the divine is absent and human experience is completely nullified and irrelevant for making ontologically real claims about the world. From this privileged standpoint - "the starry heavens above me" - he proceeds to formulate a "rationalist"/ "idealist" metaphysics - "the moral law within me" - to organize the chaos of colliding human bodies whose main characteristic now is the (noumenal) "free will," i.e., the ability to move the body outside of absolute determinism.

This interpretation finds an explicit support in a passage of Kant that makes the connection between the void in the sky (the place of infinite transmutability) and the liminal void on earth (the place of existential chaos and suspension) fully transparent: "But so long as they do not have the force of certainty, I cannot exchange my duty (as a liquidum) for a rule of expediency which says that I ought not to attempt the impracticable (i.e., an illiquidum, since it is purely hypothetical)" [Kant 1991: 89]. ${ }^{9}$ In this crucial but often overlooked passage, Kant argues that it is the moral categories of pure reason (the moral duty and the moral law) that can say something about the real nature of (historical) reality. As Kant confesses, it is the liquidum that is the source and expression of such categories; it is the place where the self has to situate itself in order to see the truth about history and how to achieve history's desirable ends. Accordingly, everything that has form is unreal and hypothetical, while everything that is formless (liquid) is real and absolutely true. I take this to be the clearest confession of the metaphysics of the liminal void in Kant's work.

In regard to the modernist interpretations of the French revolution, it is precisely this successful rationalization of the void in the sky and of the void on earth that makes Kant's transcendental philosophy so appealing and also in important ways misleading. In his political writings, Kant's transcendental reasoning produced a human ontology and philosophy of history built around the concepts of progress, cosmopolitan republicanism, universal right and a "pure" rational/moral religion [2001; 1991]. By following the basic assumptions of this meta-historical language, modernist interpretations and analyses of the revolution remain blind to the experiential source of their own narrative (the liminal void), and consequently, they cannot integrate the sacred as the concern with the divine into the discussion on the transformation of political order, nor can they grasp the specific symbolization of the sacred as void in the modern understanding of power. The obvious problem here is that human experience is not solely about establishing the objective limits of our bodies following the precepts of the transcendental mind, but also about the spiritually transformative crossing of existential limits [Szakolczai 2015; Dilthey 1988]. Accordingly, Kant simply fails to see that the "limit" is not just a mental tool to establish objective conditions of knowledge, but also a real-life possibility, a situation of being "at the limit" that in turn must have implications for the very idea of knowledge/for epistemology. ${ }^{10}$ This is to say that the reality of human embodiment creates a history that brings with itself an ontological-metaphysical dimension to human life that must be made a part of the social scientific analysis. It is to recognize that faith belongs to the symbolic and representational realities of any political and knowledge regime and that this, in turn,

9 The sentence was published in September 1793. It will be remembered that this is the moment at which the revolution was already inside the quasi-apocalyptic phase of civil war, all out international war and the reign of terror.

10 See on this point also the late Wittgenstein [2002]. 
requires of social scientific practices of knowledge production the methodological normalization of metaphysics.

\section{The French Revolution between Historic Melancholy and the Narrative of Social, Economic, and Political Rationalism}

While attempting to capture the main narrative dimensions of the enormous cross-disciplinary scholarship on the French revolution, the following will only focus on historiography. There are two reasons behind this "reductionism." The first is that historians provide the narratives upon which more theoretical and social scientific studies operate. The second refers to the fact that the latter studies work mostly well within the methodological premises of the historians' narratives, an unsurprising situation given that academic boundaries across the human sciences are largely artificially constructed.

To start with, the historical discussions can be grouped into four broad stages of development. ${ }^{11}$ The first begins with the revolution itself stretching through most of the 19th century. This could be termed, paraphrasing the work of Peter Fritzsche [2004], the stage of the melancholy of history in which the political and religious dimensions of the revolution were fully recognized, prompting that many existential tribulations to fill the "void" left behind by a broken society [Orr 1990; Dunn 1994; Goldhammer 2005]. After this first stage came the advent of socialist and Marxist accounts. The narrative of social, economic determinants of the revolution took thus over and became the orthodoxy of the first half of the 20th century, up until the mid-1970s [Sewell 1994: 22-25]. The strand of literature that questioned these Marxist and socialist assumptions and marking the third stage in the development came to be known as revisionism. This emphasized the political dimension of the revolution [Furet 1971] and also produced a series of studies steeped into the analytical category of culture broadly defined [Hunt 1984; Ozouf 1988; Furet 1997]. The revolution its causes, processes, and consequences - became the playing ground for political identity - building through collective action and discursive and ritual practices. Finally, the latest development points towards what some have called the "neoliberal" or the "post-revisionist" trend. Common to this trend is a renewed emphasis on social conflicts and the re-immersion of the revolution in the array of concrete social and political interests and antagonisms to be found across the French society [Kates 2001; Popkin 2002]. Social classes refer now simply to the capacity of groups to define their interests in extraordinary circumstances.

What are we to make of all these narratives on the French revolution? From the perspective of my methodological argument, there are two aspects that have to be highlighted. ${ }^{12}$ To start with, the Marxist/socialist, revisionist and post-revisionist or "neoliberal" directions of research mentioned above follow a narrative that does not move beyond the philosophical underpinnings of moderno-centrism. They hence reify a rationalist language that - following the Kantian method of the "condition of possibility" - reduces the problem

11 For good and comprehensive reviews of the 20th century historiography of the French Revolution, see Stone 2002: 1-13; Doyle 1999: 5-42; Popkin 2002; Kates 2001; Sewell 1994: 22-33.

12 Here I am skipping over the first stage as it cannot be situated within a scientific discourse strictly speaking. However, its narrative of the "religious" nature of the French revolution is important as it connects neatly with the problem of the sacred discussed later. 
of human experience to one of its constitutive parts and its measurement [Taylor 1995]. Since metaphysics as a vertical axis reaching for the divine has been scientifically outlawed, what remains in the open is a metaphysics that can only look down, breaking reality in ever "smaller" constitutive parts [Tyson 2015]. One of the upshots of this development is that "objectivity" across the human and social sciences follows the 19th-century evolutions of modern philosophy regarding the dichotomies between subject/object, agency/structure, and philosophical materialism/philosophical idealism [Szakolczai 2004]. In such a situation, the battle for scientific "objectivity" regards defining the element of reality that constitutes prima causa in the explanatory framework and is often grasped as a field of exclusion/combination between such dichotomies.

In this respect, my argument is that the discussion of "political ideas/culture/discourses" versus "individual interests and group factors" versus "material socio-economic determinants" underlying the scholarly debates between orthodox, revisionist and neoliberal/ post-revisionist historians of the French revolution, has led unavoidably to a narrative and theoretical deadlock. This is so because the three main positions on the revolution run in a circle and they can do so endlessly. Instead, what we need is an analytical shift in terms of the problem. Having their experiential source in the liminal void of transcendental philosophy, the presented narratives miss the fact that in our quality as embodiments, human beings can remain suspended in an existential void. In other words, moderno-centrist approaches cannot grasp that part of the revolutionary dynamic were emotional charges with the void, the state of existential suspension and its symbolization in actual reality. Further, the problem of the sacred as the concern with the divine is in this way also entirely purified out of the reality of the revolution, and therefore also from the process of understanding it.

To conclude, this is to acknowledge that any social scientific attempt to explain historical phenomena must refer the underlying social processes back to human spirituality, i.e. to the problem of human beings and the experience of life specifically as the crossing of ontological limits, with all that this implies in the emergence of human difference and of new practices of existence out of the boundlessness of historical events. The purpose of social scientific inquiry cannot be reduced to the Kantian understanding of "objectivity" along the mentioned dichotomies, while the "real" world out there cannot be couched exclusively in terms of a philosophy of history circumscribed by the symbol of Kantianism. This means that unless one postulates the liminal void as a point of absolute knowledge, one cannot analyze and interpret the French revolution simply as a struggle between progressive and non-progressive forces, nor frame this discussion within a rationalist-utilitarian conception of human beings characteristic of Marxist/socialist and liberal (r)evolutionism.

\section{The French Revolution and the Modern Democratic Imagination: The People's Two Bodies - or, The Passage from Sanctity to the Sacred}

The remainder of this paper is devoted to capturing the ordering principle of reality that emerged on an experiential level during the French revolution and thus establishing its lasting consequences. To this purpose, I am building on the works of Harald Wydra and Claude Lefort, the former providing the most consistent and systematic attempt of 
the last decade to construct a political anthropology of modern democracy [Wydra 2007, 2012, 2015a, 2015b].

Wydra argues that thinking modern democracy with liminality requires going beyond the juridical-institutional thought formulas on popular sovereignty and the corresponding models of political theory propounding a fictional contractualism. It also requires understanding political order beyond the methodological individualism of equally fictional rational and egoistic agents that are "free" to and choose among a range of convenient options [Wydra 2015a: 3-4; Wydra 2015b: 201]. This is so because modern democracies have their origins in historically contingent crises that endow them with an ambiguous nature. The ambiguity refers to democracy's "permanent interregnum," or the paradoxical state of a permanent authority vacuum based on the promise of emancipation on the one hand, and the need to rule and hence to possess a center of authority on the other [Wydra 2015b: 183-186]. Drawing on ideas from Claude Lefort and Ernst Kantorowicz, Wydra even speaks in this context of the "people's two bodies," the actual sociological reality of the people as a fractured and fragmented sociality, and the symbol of the people as one, as an imagined whole subdued to authority [2015b: 187].

However, how did the people's two bodies come about? Here the crucial insight is that liminal crises were overcome historically through a combination of institutional-legal and ritual responses. In circumscribing the emergence of democratic power, the emphasis must fall on the latter and this in a double way. The first relates to the simple point that pre- and non-democratic institutional practices had to collapse in order for democracies to emerge: people weren't born democratic, they became so in conditions of existential uncertainty and historical contingency. Therefore, bringing order in an extra-legal social context could only be achieved by experiencing ad-hoc new ritual forms of political representation. The second way refers to the fact that building a community of equals implied not only spontaneous crowd politics in ritual processions but also an original violence that was "channeled" through a particular type of ritual, that of human sacrifice [Wydra 2015b: 190-191]. In other words, the claim to transparency and demystification of political power, corresponding to the canonic reading of modern democracy, hinges on the ways in which the ritual responses to liminal crises created a new lasting sense of the sacred and the profane, a trans-generational emotional bond carrying community spirit and consensus. As Wydra observes, rituals are always thought to be in connection with sacred things, and the rites of democracy are not different as they disclose the sacred of the people as a unified entity, as something with an essence. Put it differently, the "sacrality of symbols is the way in which the object is more than the mere sum of its parts and points to something beyond itself" [2015b: 191]. Wydra's last statement on the emergence of political order offers precisely such a systematic inquiry into the co-constitutive formation of politics and the sacred [2015a]. Important to specify here is that for Wydra, the sacred is not a religious doctrine, a metaphysical belief or a foundational principle of sovereign politics, but a constitutive force transforming political goals, aspirations and moral judgments [2015a: 5-6]. This is condensed in the striking sentence that "If politics is not engaged with the sacred, it is not politics" [2015a: 16]. As such, what sustains democracy over time (and any other regime) as an experience and existential practice is its underlying ritual process, its permanent dialogue with the sacred as brought into being during the liminal crisis. 
Yet - following a genealogical and reflexive spirit - this paper does not deal with an insignificant instance of the "sacred," but with the actual event-sequence that shows the process by which a particular form of the "sacred" itself was historically constituted. We know that the sacred (le sacré) did not exist as an explicit, meaningful category of existential representation before the French revolution, being applied at most only to the person of the king. It is with this event that the sacred came to be expanded to social and political institutions in what can be seen as an immanentization of human spirituality [Lefort 2006; Voegelin 1986]. Before the French revolution and the modern age, the equivalent of the sacred was Christian sanctity, the idea and practice of saintliness as emerged during the Middle Ages [Vauchez 2005] and as it was still performed ceremonially at the court of Louis XVI [Caiani 2012]. In this sense, in order to capture the transformation from the sanctity of power to the political power of the sacred, we have to go beyond an understanding of the sacred that excludes a dialogue with the divine, as this is the very consequence of the revolution itself. At this point comes the brief discussion of the sacred empty place of power and its meaning.

\section{The French Revolution as Historical Mediation of the Democratic Empty Place of Power}

The idea of an empty place of power was initiated by French philosopher Claude Lefort in the context of his extensive efforts to understand the modern democratic imagination and the problem of modern totalitarianism through the methodological/ontological distinction between politics and the political [Lefort 1986, 1988; Flynn 2012]. The fact that he came up with a concept aimed to capture the "political" of modern democracy while specifically reflecting also on the French revolution can only provide more empirical weight to my analysis. In short, the politics of modern democracy means that "the locus of power is an empty place, it cannot be occupied - it is such that no individual and no group can be consubstantial with it - and it cannot be represented" [Lefort 1988: 17]. In other words, nobody can own the state or appropriate power indefinitely because the essence of modern democracy does not lie in a specific positive determination: not in a metaphysical/religious/transcendental principle, not in certainty, and not in a substantive identity. Rather, its essence is that the empty place of power points towards the absence of such things, as modern democracy strives for pure self-immanence: it does not refer to an outside, nor to an inside; not to the materialization of the Other, nor of the One [1988: 225-226].

In these thoughts, one can already see the first serious cracks in the deceptive powers of what we are dealing with. This is so because saying that a "place of power" does not embody a principle or a substantive identity, does not equal on the plane of reality with no principle/identity, but with a different kind of principle/identity; just as for example an anti-metaphysics is not a non-metaphysics but a different metaphysics, and an anti-theology is not a non-theology, but another theology; or just as the truth about "truth being relative" is not a non-truth but another truth, namely the truth that relativism wants to embody. ${ }^{13}$ Similarly, "the power of nobody" - a perfectly accurate observation on the empty place of power - is not the power of "nobody," but of some-thing which is yet another

13 This is also why epistemological relativism is self-contradictory. 
body. Lefort was to a degree aware of the problems posed by his observations although he was unwilling or unable to formulate this beyond the following very important statement. At the end of one of his most famous essays on the French revolution and the "theologic-political" frame of modern democracy, Lefort said:

We must recognize that [...] any move towards immanence is also a move towards transcendence [...] any attempt to explain the contours of social relations implies an internalization of unity [...] any attempt to define the objective, impersonal entities implies a personification of those entities. The workings of the mechanisms of incarnation ensure the imbrication of religion and politics even in areas where we thought we were dealing simply with purely religious or purely profane practices or representations [1988: 254-255].

So what is this hidden body, or this some-thing of the empty place of power? What is the "theologic-political" Lefort attempted to grasp? How do Wydra's two bodies of the people actually communicate with each other, what lies in-between them allowing them to capture form, each in the light of the other? What is their open-clearing (Heidegger)? In order to answer this same one question, we need to get a different angle on Lefort's decisive insight into the empty place of power. In short, the problem with Lefort's "theologic-political" is not that it is wrong but that it refuses to go the extra mile and disclose its own experiential source in the liminal void, thus perpetuating the constitutive failure of Kantian thought, only in a phenomenological disguise. To understand this we need to look at the following statement: "Of all the regimes of which we know, it [modern democracy] is the only one to have represented power in such a way as to show that power is an empty place and to have thereby maintained a gap between the symbolic and the real" [Lefort 1988: 225]. While the first part of the sentence is correct, the second is simply not. No society can actually maintain a gap between the symbolic and the real, the empty place of power and the "theologic-political" being, in fact, the symbolization of a very peculiar some-thing. In line with the argument made in this paper, this some-thing is the liminal void itself, the "positive" determination ordering our world and making thus the juncture between the real and the symbolic. Seen from such a perspective the thought that thinks (and "sanctions" or "rationalizes") modern democracy through the empty place of power is a type of metaphysics of the liminal void. To my knowledge, Lefort never problematized the question of metaphysics in his own thought, and this is exactly also the reason why Lefort's movement of thought is capable of bringing the politics of modern democracy into the light while concealing in the same time its constitutive power. In other words, we only have to let Lefort speak, and sooner or later we will stumble on the liminal void and how this makes the junction between the symbolic and the real.

Unsurprisingly, this is what Lefort has to say when he grasps the democratic moment: "Democracy is instituted and sustained by the dissolution of the markers of certainty. It inaugurates a history in which people experience a fundamental indeterminacy as to the basis of power, law, and knowledge, and as to the basis of relations between self and other, at every level of social life" [1988: 19]. Further, "this phenomenon implies an institutionalization of conflict" [1988: 17]. In a nutshell, this all but entirely overlaps with the experience and depiction of social liminality and the liminal void. This refers exactly to the condition of liminal fluidity: to the quasi-apocalyptic and terrifying experience of levelling and losing one's meaningful categories of existence; it refers to the institutional channelling of 
conflicts once all extra-legal means have been exhausted; and it also refers to the mimetism of conflict: the internalization of schismatic behaviour and the rise of ideologically defined identity politics as an artificial creation of difference and sameness at the heart of the mechanism of power.

However, to say that the real and the symbolic of modern democracy are ordered by the liminal void, and to say that the imaginary of modern democracy constructs the metaphysics of the liminal void making the junction between the real and the symbolic, does not say yet what is implied, concretely and historically, in the liminal void and its metaphysics. It does not say what exactly is the sacred of the empty place of power, or what has been sacralized becoming thus a foundational touchstone for the modern democratic imagination and its deviant totalitarian forms.

\section{The Sacrifice of Louis XVI: The Third Body of the People, or How the Liminal Void Captured Form in the Sacrifice of the Christian Father}

In order to answer this question, and indicate how the democratic imagination and implicitly the modernist literature on the French revolution blur our vision, we need to turn to the tragic figure of Louis XVI. To my mind, the key to unlocking the puzzle lies in understanding the ways in which the liminal void managed to catch form existentially through the sacrifice of the Christian Father. This is to say that the sacrifice of Louis XVI did not simply take place as an act condemning kings and oppressive monarchic power as commonly seen in the literature. Rather, the peculiar nature of the sacrifice of Louis XVI refers to the fact that it was undertaken - consciously or not - against the power and symbol of a Christian prince standing analogically for the Christian Father. This has two dimensions.

In an inspired essay on the rise of modern nihilism, Albert Camus [2000] was acutely aware that the decapitation of Louis XVI figures as the symbolic and historical condemnation of the Christian God. Yet, in most 20th century histories of the revolution, the person and fate of the king, his trial, and execution have a very low profile [Hardman 2000]. This is all the more intriguing as overcoming at the social level the sacred monarchy of divine right and in a certain way also the Christian metaphysical world-view underlying it, was so to speak the very core of the existential process of the revolution. As shown elsewhere [Roman 2015], academic scholarship displays three paradigmatic positions regarding the sacred dimension of the French monarchy: one of "illusionism" in which the sacred is acknowledged as a social reality and used analytically only in so far as it can justify ex post facto the republican creed [Walzer 1992], one of "negation" in which the sacred while recognized, is also simultaneously denied any role in social theory and the social process [Feher 1987], or simply one of "absence" in which the sacred is neither here, nor there, utterly irrelevant for judging and understanding the revolution [Furet 1996: 122]. However, as argued before, thinking the revolution with liminality makes clear that the transformation of the sacred is essential to understanding the revolution's lasting effects and the meaning of the empty democratic space of power. Therefore, the destruction of a Christian metaphysical symbol through the sacrifice of Louis XVI cannot be separated in any sensible way from the (post-) revolutionary dynamics at the level of knowledge, politics, and society more largely. 
There is, however, a layer of truth and reality in this argument that is not uncovered by adopting only the symbolic perspective of political anthropology. This is so because not only the ritual murder of the king is important here (Louis XVI as a symbol of the Christian prince/Father), but also the actual person of Louis, this element shifting the discussion to the level of philosophical anthropology. By following Imitatio Christi in the midst of crisis and being sacrificed at that, Louis shows how in a very concrete way the ritual process of the revolution was oriented against the Christian father (Louis XVI as Christian prince and the analogical reality of the Christian father). We cannot truly understand or think the dynamic of the revolution if we do not recognize the incredible magnitude of this fact. While such a claim cannot be fully substantiated within the boundaries of a paper, it is nevertheless central and needs to be stated as such, indicating its main signposts. The first aspect of this claim regards Louis XVI's Christian life conduct. Here things are quite clear as two recent monographs go at great length emphasizing and bringing into the open the strong Christian faith driving Louis XVI in his actions and relations to the world surrounding him [Hardman 2000; Caiani 2012]. To put it short: this was neither an absolutist nor an "enlightened" king. The second and thornier issue concerns understanding the exact nature of Imitatio Christi practiced by Louis XVI. Based on my reflections on the French revolution, the solution proposed here to solve this problem appeals to René Girard's anthropological and comparative work on the history of religion and mythology. This has two major reflexive developments. In a first step, Girard [1979] advances a sui generis theory of mimetic desire that explains how all (founding) myth and culture is to be traced back to an original sacrificial violence: a scapegoat is sought out in order to bring about communal pacification. In a second step, Girard substantiates how this sacrificial sacred marking the threshold of hominization was overcome historically through the Revelation of Christ. According to him, the Gospel texts contain the most effective way of unmasking sacrificial violence and the mechanism of scapegoating [1986], this being also the main reason why we are capable of grasping the instrumental lie and the mythological strata behind human sacrifice in the first place.

Without going any further into the complexities of Girardian anthropology, the key aspect to highlight is that Imitatio Christi refers in this perspective precisely to a practice of life that does not succumb to sacrificial violence when confronted with it, rather recognizing, exposing and overcoming it. And here Louis XVI was uniquely situated inside the French society at once to observe as a privileged "outsider" the unfolding sacrificial process and also to become its most important symbolic and existential object of polarization. Historians up to this day are puzzled by the duplicitous and contradictory nature of Louis' character and actions during the revolution. Yet beyond such observations and in the light of the above, it is vital to see that Louis was living his own inner passion, torn between the political exigencies that come from being a king and his conscious convictions and diagnosis of the situation. Perhaps the most striking document disclosing his inner torment is the letter ${ }^{14}$ sent to his emigrated brothers from September 1791. In this letter, he is explaining the reasons for accepting the new constitution and expressing his resolution to seek - even beyond any hope of success - a course of action that avoids, by all means, the perils of civil and international war. While elements of his attempt to hold the right balance and pacify

14 For the content of the letter [see Hardman 2000: 172-175]. 
the French society at any personal cost are visible throughout the revolutionary crisis, it is this letter and the period before the fall of the monarchy until his execution (spring 1792 - January 1793) that display the king's Imitatio Christi with greatest clarity, generating the well known myth of a king who was not capable to reign, but certainly knew how to die [Dunn 1994; Hardman 2000]. ${ }^{15}$

Summing up, thinking the execution of Louis XVI from the perspective of these two mutually reinforcing arguments - one at the level of political anthropology and one concerning the philosophical anthropology of the king's person - the symbolic and existential sacrifice of the Christian Father emerges as exactly the third hidden body on which the people's two bodies of modern democracy depend on surviving, mediating the relationship between them and orienting their history, and their sociological and "metaphysical" reality.

\section{Conclusion}

Methodological Contributions. This paper has attempted to bring contributions to the scholarship of the French revolution both on a substantive level, and also methodologically, thus going beyond the field and into the social and human sciences more generally. As regards methodology, the paper has argued for the relevance of a political anthropological take on the French revolution. It has shown that modernist interpretations and analyses of the revolutionary phenomenon reduce the latter to economic, social and political rationalism, itself underpinned by a tricky and quite simply flawed progressive philosophy of history. Instead, using the approach of liminality and focusing on the exact nature of "experience," this paper has gone beyond Durkheimian sociology and Kantian philosophy in three significant ways. First, the paper was able to integrate into the discussion the essentially always overlooked problem of the existential void, showing that key parts in the revolutionary transformation were emotional charges with the liminal void and the enduring symbolization of this void in terms of the sacred empty democratic place of power.

Second, this paper has suggested that liminality with its focus on the ritual process offers a methodology of social change that completes the insights gained by genealogical, processual and "event" sensitive social theory and historical sociologies. Third, the paper has emphasized the existentially open nature of human experience bringing to attention a concealed ontological-metaphysical dimension to human existence that cannot be simply purified out of political and social reality by the scientific method, nor "domesticated" by moderno-centrist philosophies of the liminal void. As such, the paper has argued that the sacred cannot be reduced to a Durkheimian category of mere social construction, and constitutes an invitation and opportunity to reflect on the methodological normalization of metaphysics in the social and human sciences. Specifically, there is a solid case to be made here for a reconsideration of classical and Christian forms of thought. In-Between the Void and Political and Social De-Christianization. On a substantive level, the paper has claimed that the process of overcoming the royal sacred and the sacrifice of Louis XVI as

15 For a social scientific analysis and demonstration of Louis XVI's pursuit of Imitatio Christi, hence going beyond narrative exposition [see Roman 2017]. 
a Christian king are the central existential axis in the dynamic of the French revolution. In view of the ritual process underlying any established political order, the ritual murder of the Christian prince cannot be taken lightly and must be formulated explicitly as a particular brand of the secularization thesis at the heart of the modern democratic imagination. This argument follows standard Weberian methodology: it identifies the conditions of emergence for a phenomenon - the people's third body as the experiential basis for the modern democratic sacred -, and its lasting effects - secularization as the ritual process of sacrificing the Christian prince and analogically, the Christian Father. ${ }^{16}$ Therefore, understanding secularization in modernity does not refer only to the problem of quantifying the public/private marginality of religion in general or its privatisation [Casanova 1994], nor to the question of determining the impact of existential pluralism on the lived experience of belief [Taylor 2007], and not to the "theologic-political" implied in the modern democratic imaginary [Schmitt 2005; Lefort 2006; Agamben 1998; Vries - Sullivan 2006]. Recognizing the reality of the people's third body indicates something different and more specific, namely that the democratic sacred guards as an ordering reality not against religion as such, but against Christian religion as a manifestation of political power and as an existential symbol of representation.

There is, however, more to the argument than just saying that in the aftermath of the French revolution Christian religion was gradually put on the Index on a historical, political and sociological level. Following the genealogical idea of "backward inference" [Nietzsche 2001: 235], it is clear that Christian inspired spirituality did not simply vanish during the French revolution and the birth of modern politics but was put to "work" by the same. In this sense, the people's third body (the modern democratic sacred) performs not just the political function of the ritual hangman of the Christian Father, but also the function of a genuine switchman, to repeat the famous Weberian metaphor, re-orienting world-images. To give just a few examples, for Camille Desmoulins and for countless revolutionaries ever since, the revolution was the real Christianity as Jesus was in actual reality a good old "sans-culotte." Further, liberals in the tradition of Kant are claiming that post-revolutionary conditions paved the way for the best of Christianity. Similarly, the various Marxists, socialist, communists, but also fascists and Nazis all claimed to make real the promises of (mostly hated) historical Christianity about "paradise" and brotherhood [Voegelin 1987; 1997]. ${ }^{17}$ As Alain Besançon [2005: 104-111] puts this, a kind of perversa imitatio took place in regard to the Old Testament (Nazism as the reverse ideology of the chosen Jewish people), and the Old and New Testaments (Communism as an immanentist messianic sect with its own redemptive agents).

It is impossible to understand the political and sociological evolutions in the European history of the past 200 years without acknowledging the existence of the people's third body and its functions. While my case is not an overarching claim about every single dynamic of post-revolutionary European history, it nevertheless sheds light on the way the "political" of modern democracy and the specific outlook of its politics determine the logic of reality

16 Of course, Christian kings have been assassinated or sacrificed in public before Louis XVI, yet not for the reason of being Christian kings per se (see, for example, the execution of Charles I in England).

17 For a concrete and particularly insidious example on this activity of forging [see Figes - Kolonitskii 1999] who show how the Bolsheviks attempted to win over Russian peasantry by claiming to be Christians, not any kind, but the best. 
underpinning our contemporary lives. It also shows that the problem of existential nihilism is not simply a matter of the political extremes of modernity but also, via the liminal void, of the "centre" and the very way in which modern democratic imagination seems incapable of naturalizing any kind of lasting "tradition" that goes beyond the field of an empty space and the mythological strata of pure self-immanence. The snag here is that the Doppelgänger of this pure self-immanence is nothing other than the limitless sacred with its inbuilt proclivity to limitless conflict and perpetual crisis.

\section{Bibliography}

Agamben, Giorgio [1998]. Homo Sacer: Sovereign Power and Bare Life. Stanford: Stanford University Press. Alexander, Jeffrey C. - Giesen, Bernd - Mast, Jason [2006]. Social Performance: Symbolic Action, Cultural Pragmatics, and Ritual. Cambridge: Cambridge University Press.

Besançon, Alain [2005]. Le Malheur du Siècle. Sur le Communisme, le Nazisme et l'Unicité de la Shoah. Paris: Editions Perrin.

Caiani, Ambrogio A. [2012]. Louis XVI and the French Revolution. Cambridge: Cambridge University Press.

Camus, Albert [2000]. The Rebel. London: Penguin.

Casanova, José [1994]. Public Religion in the Modern World. Chicago: University of Chicago Press.

de Vries, Hent - Sullivan, Lawrence E. (eds.) [2006]. Political Theologies: Public Religions in a Post-Secular World. New York: Fordham University Press.

Dilthey, Wilhelm [1988]. Introduction to the Human Sciences. An Attempt to Lay a Foundation for the Study of Society and History. Translated by Betanzos, R. J. Detroit: Wayne State University Press.

Doyle, William [1999]. Origins of the French Revolution. Third Edition. Oxford: Oxford University Press.

Dunn, Susan [1994]. The Deaths of Louis XVI: Regicide and the French Political Imagination. Princeton: Princeton University Press.

Durkheim, Émile [1967 (1915)]. The Elementary Forms of Religious Life. New York: Free Press.

Edwards, Jeffrey [2000]. Substance, Force, and the Possibility of Knowledge. Berkeley: University of California Press.

Eisenstadt, Shmuel N. [1995]. The Order-Maintaining and Order-Transforming Dimensions of Culture. In. Power, Trust, and Meaning: Essays in Sociological Theory and Analysis of S. N. Eisenstadt. Chicago: Chicago University Press, pp. 306-327.

Feher, Ferenc [1987]. The Frozen Revolution: An Essay on Jacobinism. Cambridge: Cambridge University Press.

Fiala, Andrew [2004]. Introduction to the New Edition. In. Immanuel Kant. Critique of Pure Reason. New York: Barnes and Noble Books, pp. vii-xiii.

Figes, Orlando - Kolonitskii, Boris [1999]. Interpreting the Russian Revolution. The Language and Symbols of 1917. New Haven: Yale University Press.

Flynn, Bernard [2012]. Lefort as Phenomenologist of the Political. Constellations 19 (1): 16-22.

Foucault, Michel [1979]. Discipline and Punish: The Birth of the Prison. New York: Vintage.

Foucault, Michel [1984]. Nietzsche, Genealogy, History. In. Rabinow, Paul (ed.). The Foucault Reader. London: Penguin, pp. 76-100.

Foucault, Michel [2010]. The Government of Self and Others. Lectures at the Collège de France 1982-1983. Basingstoke: Palgrave.

Fritzsche, Peter [2004]. Stranded in the Present: Modern Time and the Melancholy of History. Cambridge, MA: Harvard University Press.

Furet, Francois [1971]. Le Catechisme Revolutionnaire. Annales: Economies, Sociétés, Civilisations 26: 255-289.

Furet, Francois [1996]. The French Revolution. 1770-1814. Oxford: Blackwell.

Furet, Francois [1997]. Interpreting the French Revolution. Cambridge: Cambridge University Press.

Girard, René [1979]. Violence and the Sacred. London: Johns Hopkins University Press. 
Girard, René [1986]. The Scapegoat. Baltimore: Johns Hopkins University Press.

Goldhammer, Jesse [2005] The Headless Republic: Sacrificial Violence in Modern French Thought. Ithaca: Cornell University Press

Guyer, Paul - Wood, Allen W. [1998]. Introduction to the Critique of Pure Reason. In. Kant, Immanuel, Critique of Pure Reason. Cambridge: Cambridge University Press.

Hardman, John [2000]. Louis XVI: The Silent King. London: Arnold.

Horvath, Agnes [2013]. Modernism and Charisma. London: Palgrave Macmillan.

Horvath, Agnes - Thomassen, Björn - Wydra, Harald [2015]. Breaking Boundaries: Varieties of Liminality. Oxford: Berghahn.

Hunt, Lynn [1984]. Politics, Culture, and Class in the French Revolution. Berkeley: University of California Press.

Kant, Immanuel [1987]. Critique of Judgment. Indianapolis/Cambridge: Hackett.

Kant, Immanuel [1991]. Political Writings. Second enlarged edition. In. Cambridge Texts in the History of Political Thought. Cambridge: Cambridge University Press.

Kant, Immanuel [1998]. Critique of Pure Reason. Cambridge: Cambridge University Press.

Kant, Immanuel [2001]. Religion and Rational Theology. Cambridge: Cambridge University Press.

Kant, Immanuel [2002]. Critique of Practical Reason. Indianapolis/Cambridge: Hackett.

Kates, Gary [ed.] [2001]. The French Revolution. Recent Debates and New Controversies. London: Routledge.

Lefort, Claude [1986]. The Political Forms of Modern Society Bureaucracy, Democracy, Totalitarianism. Cambridge, MA: MIT Press.

Lefort, Claude [1988]. Democracy and Political Theory. Cambridge: Polity Press.

Lefort, Claude [2006]. The Permanence of the Theologico-Political? In. de Vries, Hent - Sullivan, Lawrence E. (eds.) Political Theologies: Public Religions in a Post-Secular World. New York: Fordham University Press, pp. 148-187.

Nietzsche, Friedrich [1967]. On the Genealogy of Morals. New York: Vintage.

Nietzsche, Friedrich [2001]. The Gay Science. With a Prelude in German Rhymes and an Appendix of Songs. Cambridge: Cambridge University Press.

O'Connor, Paul [2014]. The Vanishing Stars: Natural Experience and Meaning. International Political Anthropology 7 (1): 47-72.

Orr, Linda [1990]. Headless History: Nineteenth-Century French Historiography of the Revolution. Ithaca: Cornell University Press.

Ozouf, Mona [1988]. Festivals and the French Revolution. Cambridge: Harvard University Press.

Popkin, Jeremy D. [2002]. Not Over After All: The French Revolution's Third Century. Journal of Modern History 74: 801-821.

Roman, Camil F. [2015]. Liminality, the Execution of Louis XVI and the Rise of Terror During the French Revolution. In. Horvath, Agnes - Thomassen, Björn - Wydra, Harald (eds.). Breaking Boundaries: Varieties of Liminality. Oxford: Berghahn, pp. 141-163.

Roman, Camil F. [2017]. The French Revolution as a Liminal Process: Towards a Political Anthropology of Radical Social Changes. Doctoral Thesis. Cambridge: University of Cambridge.

Roman, Camil F. [2018]. The Revolutionary and Napoleonic Wars in the Prussian Political Imaginary: a Political Anthropological Genealogy of the "Special" German-French Relations. Journal of International Relations and Development 21 (2): 322-345.

Rynasiewicz, Robert [2014]. Newton's Views on Space, Time, and Motion, online version at http://plato .stanford.edu/entries/newton-stm (accessed 3 March 2016).

Sallis, John [2012]. Logic of Imagination. The Expanse of the Elemental. Bloomington: Indiana University Press.

Schmitt, Carl [2005]. Political Theology: Four Chapters on the Concept of Sovereignty. Chicago: University of Chicago Press.

Schönfeld, Martin [2014]. Kant's Philosophical Development, online version at http://plato.stanford.edu /entries/kant-development (accessed 12 February 2016).

Sewell, William H., Jr. [1994]. A Rhetoric of Bourgeois Revolution. The Abbé Sièyes and What Is the Third Estate? Durham: Duke University Press.

Sewell, William H., Jr. [2005]. Logics of History: Social Theory and Social Transformation. Chicago, IL: University of Chicago Press. 
Stone, Bailey [2002]. Reinterpreting the French Revolution. A Global-Historical Perspective. Cambridge: Cambridge University Press.

Szakolczai, Arpad [2000]. Reflexive Historical Sociology. London: Routledge.

Szakolczai, Arpad [2004]. Experiential Sociology. Theoria 103: 59-87.

Szakolczai, Arpad [2008]. What Kind of Political Anthropology? An External Insider View. International Political Anthropology 1 (2): 275-282.

Szakolczai, Arpad [2012]. Critique, Enlightenment and the Spectator in Kant: On the Theatrical Background to the Critical Public Sphere. International Political Anthropology 5 (2): 157-178.

Szakolczai, Arpad [2015]. Liminality and Experience: Structuring Transitory Situations and Transformative Events. In. Horvath, Agnes - Thomassen, Björn - Wydra, Harald (eds.). Breaking Boundaries: Varieties of Liminality. Oxford: Berghahn, pp. 11-38.

Taylor, Charles [1995]. The Validity of Transcendental Arguments. In. Philosophical Arguments. Cambridge, MA: Harvard University Press, pp. 20-33.

Taylor, Charles [2007]. A Secular Age. Cambridge, MA: Harvard University Press.

Thomassen, Björn [2012]. Notes Towards an Anthropology of Political Revolutions. Comparative Studies in Society and History 54 (3): 679-706.

Thomassen, Björn [2014]. Liminality and the Modern: Living Through the In-Between. London: Routledge.

Turner, Victor W. [1969]. The Ritual Process: Structure and Anti-Structure. London: Routledge.

Turner, Victor W. [1985]. On the Edge of the Bush: Anthropology as Experience. Tucson: University of Arizona Press.

Tyson, Paul [2015]. Returning to Reality: Christian Platonism for Our Own Times. Cambridge: The Lutterworth Press.

van Gennep, Arnold [1960 (1909)]. The Rites of Passage. London: Routledge.

Vauchez, André [2005]. Sainthood in the Later Middle Ages. Cambridge: Cambridge University Press.

Voegelin, Eric [1974]. The Ecumenic Age. Order and History, Vol. 4. Baton Rouge: Louisiana State University Press.

Voegelin, Eric [1986]. Political Religions. Lewiston, NY: Edwin Mellen.

Voegelin, Eric [1987]. The New Science of Politics: An Introduction. Chicago: University of Chicago Press.

Voegelin, Eric [1990]. Equivalences of Experience and Symbolization in History. In. Sandoz, Ellis (ed.). Collected Works of Eric Voegelin, Volume 12, Published essays 1966-1985. Baton Rouge: Louisiana State University Press, pp. 115-133.

Voegelin, Eric [1997]. Science, Politics, and Gnosticism: Two Essays. Washington D.C.: Regnery Publishing. Walzer, Michael [1992]. Regicide and Revolution. In. Walzer, Michael (ed.). Regicide and Revolution. Speeches at the Trial of Louis XVI. New York: Columbia University Press, pp. 1-89.

Weber, Max [2016]. Die Protestantische Ethik und der Geist des Kapitalismus. Wiesbaden: Springer.

Wittgenstein, Ludwig [2002]. Tractatus Logico-Philosophicus. London: Taylor \& Francis.

Wydra, Harald [2007]. Communism and the Emergence of Democracy. Cambridge: Cambridge University Press.

Wydra, Harald [2012]. The Power of Symbols - Communism and Beyond. International Journal of Politics, Culture and Society 25 (1-3): 49-69.

Wydra, Harald [2015a]. Politics and the Sacred. Cambridge: Cambridge University Press.

Wydra, Harald [2015b]. Liminality and Democracy. In. Horvath, Agnes - Thomassen, Björn - Wydra, Harald (eds.). Breaking Boundaries: Varieties of Liminality. Oxford: Berghahn, pp. 183-203.

Wydra, Harald - Thomassen, Björn. [Forthcoming]. Handbook of Political Anthropology. Cheltenham: Edward Elgar.

Camil Francisc Roman completed a doctoral thesis on the political anthropology of the French Revolution at the University of Cambridge. He has a highly cross- and interdisciplinary focus on modern revolutions as symbolic and experiential processes of transforming modes of consciousness. He is interested in reflexive and interpretative approaches to the human sciences, with an emphasis on anthropologically and historically oriented theory. The long-term goal of 
his research is to contribute to our understanding of European modernity, inquiring into the multi-faceted and tightly connected phenomena of imperialism/colonialism, secularization and globalization and into the ways in which the modern political and social construction of human nature interferes with human flourishing and the possibilities of a life with meaning. He is currently working on the research monograph The French Revolution as a Liminal Process, forthcoming with Routledge in 2019. 